\title{
Academic Freedom: Understanding and Experience of Higher Education Lecturers in Indonesia
}

\author{
Nurul Huda S. A. ${ }^{1,2, *}$, Suyanto ${ }^{3}$, Badrun Kartowagiran ${ }^{3}$, Caly Setiawan $^{1}$, Himawan Putranta $^{3}$ \\ ${ }^{1}$ Department of Research and Educational Evaluation, Graduate School of Yogyakarta State University, Indonesia \\ ${ }^{2}$ Department of Islamic Education, Institut Studi Islam Fahmina (ISIF) Cirebon, Indonesia \\ ${ }^{3}$ Department of Science Education, Concentration of Physics Education, Graduate School of Yogyakarta State University, Indonesia
}

Received June 24, 2020; Revised August 3, 2020; Accepted August 25, 2020

\section{Cite This Paper in the following Citation Styles}

(a): [1] Nurul Huda S. A., Suyanto, Badrun Kartowagiran, Caly Setiawan, Himawan Putranta, "Academic Freedom: Understanding and Experience of Higher Education Lecturers in Indonesia, "Universal Journal of Educational Research, Vol. 8, No. 10, pp. 4671-4683, 2020. DOI: 10.13189/ujer.2020.081036.

(b): Nurul Huda S. A., Suyanto, Badrun Kartowagiran, Caly Setiawan, Himawan Putranta (2020). Academic Freedom: Understanding and Experience of Higher Education Lecturers in Indonesia. Universal Journal of Educational Research, 8(10), 4671-4683. DOI: 10.13189/ujer.2020.081036.

Copyright $\bigcirc 2020$ by authors, all rights reserved. Authors agree that this article remains permanently open access under the terms of the Creative Commons Attribution License 4.0 International License

\begin{abstract}
Academic freedom is a universal concept inherent in the academic community of higher education. But in its implementation, it is always diverse because it attached to the cultural context and locality of the community. This research aims to find out the description of lecturers' understanding of academic freedom and determine challenges in the field based on their experience. Data were collected by in-depth interviews with 15 informants from 10 tertiary institutions located in 5 major islands in Indonesia. Data analysis was performed by describing data qualitatively using analytic reduction of statement identification, determination of core themes, and essence descriptions. The results showed that lecturers have an understanding of academic freedom to conduct or not to carry out activities based on the disciplines they engaged in, in the aspects of teaching, research, publication, and community service without any intervention. Lecturers also get treatment of restrictions on academic freedom conducted by leaders of higher education institutions, fellow lecturer colleagues, government officials, and community groups. Dialogue is the most common way lecturers do when faced with restrictions in academic freedom. Thus, it is important to formulate a broader and more detailed conceptualization to minimize the interpretation of the misuse of interests. Strengthening networks between lecturers and international institutions concerned with academic freedom is a form of academic policy.
\end{abstract}

Keywords Academic Freedom, Academic Policy, Dialogue, Indonesian Lecturers, Restriction on Academic Freedom

\section{Introduction}

Academic freedom is a concept that closely related to college life $[1,2]$. The idea of the founding principle of higher education is to create intellectuals who are humane, able to think, and work for society and the country $[3,4]$. In the dictum of the establishment of higher education (Magna Charta Universitatum) states that universities must be at the forefront in the development of scientific traditions and glorify humanity [5]. The main task of tertiary institutions is to strengthen their academic abilities and creative research [6]. Higher education is a place to gather and interact with the scientific-academic community in the context of seeking academic truth while developing the capacity of each academic community [7]. The search for truth aims to develop knowledge for the benefit of humanity and the development of human civilization. Higher education is a moral force, a place of production, and reproduction of knowledge carried out by scientists $[8,9]$. Higher education is a home where scientists gather to consider the future of humanity that is very dependent on the development of culture, science, and technology [10]. 
Academic freedom is a core value of higher education. Academic freedom is a source of protection inherent in academics [11]. However, it is important to understand that academic freedom is different from other professional work. Academic freedom is the freedom of an academic to study and conclude by his scientific field, and disseminate it in learning forums, academic forums, and publications without interference from political, religious, and institutional authorities where academics work [12]. Academic Freedom is the basis and prerequisites for higher education development [13]. Therefore, academics need absolute freedom of thought to advance knowledge, freedom to conclude and publish research results, and educate students or the public to think critically without interference from any party [14]

In this context, becoming an academic has a different construction from other professions. Conceptually, academic freedom is very general, making it possible to be understood in a variety of ways, even giving rise to various interpretations and debates [4]. There are various interpretations of academic freedom from the absence of any restrictions at all; others see academic freedom as involving no restrictions, but with clear academic responsibilities. Some define academic freedom by referring to individual and institutional freedom. Academic freedom is also interpreted as something inherent in academics, not inherent in tertiary institutions [15]. Such differences must lead to greater clarity, accuracy, and completeness in debates. The debate occurred because of the lack of clarity and consistency about what academic freedom means [16]. One of the fundamental weaknesses of the debate on academic freedom is the lack of empirical data on how academics understand the meaning of academic freedom. The first research of researchers' opinions on academic freedom is implemented in Australia and so far, there seems to be no such research [17].

However, because the concept of academic freedom is very loose, the most appropriate way of understanding is not as an abstract universal principle, but as a concrete university practice that occurs in certain relational environments [18]. Academic freedom is currently in a formidable challenge globally, so it takes a struggle so that academic life stays alive [19]. Historically, academic freedom since the beginning of tertiary institution civilization is not easy to uphold, not least sacrifice lives, imprisonment, dismissal, ban, ban, even must become an immigrant [20]. Currently, the threat of academic freedom occurs in 60 countries in the world spread across all continents of the world [21]. This real threat can only be solved if academics, universities, professional associations, and potential international bodies gather, to protect academic freedom.

In this context, tertiary institutions have laws that directly refer to higher education academic freedom, namely Constitution Number 12 of 2012 concerning Higher Education, Constitution Number 14 of 2005 concerning Teachers and Lecturers, and Constitution
Number 20 of 2003 on the National Education System [22-24]. Even though it has a strong normative foundation, the practice is still full of restrictions and threats. In the period 2014-2016, there was 18 times the threat of academic freedom, in 13 major universities in Indonesia [25]. Throughout 2019, there were also 6 types of violations of academic freedom in the form of killings in mass actions, persecution, death threats, criminalization, an improper lawsuit on lecturers, dissolution of the student press, and suspension of lecturers and students [26]. Based on various incidents of threats to academic freedom, there are several attitudes of universities carried out; first, put up a fight and dialogue with parties who disagree, with very good results, the event can still be held though. Second, engage in dialogue and resistance, but the results fail. In almost all cases, the threat ends with the defeat of the college. Third, universities are subject to pressure and the threat of academic freedom, without taking any resistance [27]. Therefore, two things are very important and become the focus of this research. First, the very general concept of academic freedom gives rise to diverse interpretations. However, empirical academic studies based on academics' understanding of academic freedom are still very rare. Second, violations and threats to academic freedom occur massively in 60 countries in the world, including Indonesia. This research will focus on how lecturers understand about academic freedom, and how they have experience limiting academic freedom and strategies so that academic freedom keep maintained.

\subsection{Research Problem}

The task of higher education can only be carried out properly if academic freedom guaranteed. Academic freedom is the right to freedom in teaching and discussing, researching, disseminating, and publishing research results. However, the general concept of academic freedom causes various interpretations potential and instead becomes a tool to silence the academic freedom of academics. Therefore, the most appropriate way to understand academic freedom is not as an abstract universal principle, but as a concrete university practice that occurs in certain relational environments, especially empirical research on academic freedom understood by academics itself is very rare [4]. Thus, empirical research on the understanding of academics about academic freedom is very important. Tracing the experience of academics who have restrictions in carrying out academic freedom is also very relevant. Tracing the empiric understanding and experience that is reflected is very interesting, how the understanding of academic freedom, when confronted with the reality of experience, has restrictions in carrying out academic freedom.

\subsection{Research Questions}

Academic freedom is a necessity and right inherent in 
academics. However, in reality, academic freedom continues under a broad threat. One reason is the universal and global concept of academic freedom, so it is open to diverse interpretations. Therefore, this research will explore the understanding of academic freedom and experiences that have restrictions in carrying out academic freedom. This research will answer the following research questions.

1. What is the understanding of lecturers about academic freedom?

2. How does experience encounter restrictions in exercising academic freedom?

3. What practical strategies are considered important so that academic freedom maintained?

\subsection{Research Focus}

This phenomenological research is focused on exploring lecturers' understanding of academic freedom; an experience he has about limiting academic freedom and strategies took so that academic freedom is maintained.

\section{Materials and Methods}

\subsection{General Background}

This research is qualitative research using a phenomenological approach [28] or transcendental phenomenology [29]. This research was conducted to explore information about lecturers' understanding of academic freedom. Specifically, this research aims to gain an in-depth understanding of how lecturers interpret and interpret academic freedom. Second, exploring the experience of lecturers has obstacles in carrying out academic freedom, and what practical strategies they do so that academic freedom keeps maintained. This research was conducted for 5 months from January to May 2020. This research is expected to be the basis for the formulation of a more empirical and contextual concept of academic freedom. It hoped that this concept would easily be understood, not only by academics but also by other parties with an interest in the academic world. Therefore, academic freedom can be implemented and can minimize the existing obstacles.

\subsection{Participant}

The research participants were lecturers from 10 tertiary institutions ( 6 public and 4 private) in five major islands in Indonesia Java, Sumatra, Sulawesi, Kalimantan, and Papua. The number of informants numbered 15 people, with female numbering 6 and male numbering 9. The research participants were 15 people based on the phenomenon of exploration design could do on heterogeneous participants' among 3 to 15 people [28]. Meanwhile, the characteristics of the profile of respondents involved in this research can be shown in the following Table 1.
Table 1. Profile of Participants from Five Major Islands in Indonesia

\begin{tabular}{|c|c|c|c|c|}
\hline \multirow{2}{*}{ Name } & \multicolumn{2}{|c|}{ Gender } & \multirow{2}{*}{ Total } & \multirow{2}{*}{ Institution } \\
\hline & Male & Female & & \\
\hline $\mathrm{AK}$ & 1 & - & 1 & HE-1 \\
\hline BR & - & 1 & 1 & HE-1 \\
\hline CK & 1 & - & 1 & HE-2 \\
\hline DK & 1 & - & 1 & HE-2 \\
\hline ER & - & 1 & 1 & HE-3 \\
\hline FK & 1 & - & 1 & $\mathrm{HE}-4$ \\
\hline GR & - & 1 & 1 & $\mathrm{HE}-4$ \\
\hline HK & 1 & - & 1 & HE-5 \\
\hline IR & - & 1 & 1 & HE-6 \\
\hline JK & 1 & - & 1 & $\mathrm{HE}-7$ \\
\hline $\mathrm{KR}$ & - & 1 & 1 & HE-7 \\
\hline LK & 1 & - & 1 & HE-8 \\
\hline MR & - & 1 & 1 & HE-8 \\
\hline NK & 1 & - & 1 & HE-9 \\
\hline $\mathrm{OK}$ & 1 & - & 1 & HE-10 \\
\hline Total & 9 & 6 & 15 & 10 \\
\hline
\end{tabular}

All participants in this research were disguised under their respective names; AK, BR, CK, DK, ER, FK, GR, HK, IR, JK, KR, LK, MR, NK, and OK. The tenth universities in this research were also disguised as HE-1, HE-2, HE-3, HE-4, HE-5, HE-6, HE-7, HE-8, HE-9, and HE-10. The purpose of the disguised identity is to protect research participants and ensure the confidentiality of information shared and anonymity $[28,30]$. The selection of the ten tertiary institutions as a sample is because the ten tertiary institutions are spread across five major islands in Indonesia that have geographical, ethnic, and religious diversity. Meanwhile, the profile of tertiary institutions used in this research cab be shown in Table 2.

Table 2. Profile of Universities from Five Major Islands in Indonesia

\begin{tabular}{|c|c|c|}
\hline Name & Status & Geographical Location \\
\hline HE-1 & State & Java \\
\hline HE-2 & State & Java \\
\hline HE-3 & Private & Java \\
\hline HE-4 & Private & Java \\
\hline HE-5 & State & Java \\
\hline HE-6 & State & Sulawesi \\
\hline HE-7 & State & Kalimantan \\
\hline HE-8 & Private & Sumatra \\
\hline HE-9 & State & Sumatra \\
\hline HE-10 & Private & Papua \\
\hline
\end{tabular}

\subsection{Instruments and Procedures}

Data collection in this research was carried out through interviews. Interviews are conducted in the duration of 45 
to 90 minutes. Interviews were generally held in Yogyakarta and Jakarta. So that the interview can be focused and not be disturbed, all interviews are conducted in a closed room and only researchers and participants are in the room. In addition to getting good recordings, closed interviews are also a way to ensure that participants' real identities and information provided are confidential and confidential in addition to research interests [31]. Interview questions are open and general, compiled by researchers to understand the core phenomena of this research. During the interview, the researcher tried to create a conducive climate so that participants felt comfortable and free in responding to every question raised.

\subsection{Data Analysis}

Analytical reduction of participants' experience in practicing, undergoing, and practical strategies to keep academic freedom awake into a crucial part of data analysis in this research. The steps of data analysis are classified, descriptions, and variations. Categories are a large theme group. The description is the general meaning of the category. Variation is the main statement from lecturers about understanding academic freedom [32]. The data analysis procedure in this research began by converting the recorded sound from the interview into a transcript so that the information contained in it could be understood. Then do the selection and sorting of important information and statements. Important statements identified are then grouped into categories, descriptions, and variations. The final step in the data analysis procedure is writing the essence of all phenomena experienced by all participants.

\section{Results}

\subsection{Lecturer Understanding of Academic Freedom}

Research on understanding academic freedom of university lecturers in Indonesia refers to three main tasks of lecturers, namely teaching, research, and community service. Based on the three lecturer assignments, the results of this research are grouped into categories, descriptions, and variations. Categories are a large theme group. The description is the general meaning of the category. Variation is the main statement from lecturers about understanding academic freedom. Meanwhile, based on in-depth interviews conducted with participants, it can be stated that lecturers' understanding of academic freedom can be grouped into sixth categories covering the first category of freedom fully. The second category is about freedom based on scientific discipline, the third category is about freedom from campus intervention, and the fourth category is freedom from government intervention. Besides, the fifth category is about freedom from interventions in the industrial world and the sixth category is about freedom from interventions based on religion, ethnicity, and gender.

Furthermore, the sixth category can be described more broadly based on the results of in-depth interviews with participants in the following description and variations. The first category is freedom as broad as possible, which means that academic freedom is understood as the broadest freedom without any limitations that are done by a lecturer. IR who is a lecturer from HE-6 said, "By giving the widest possible freedom to lecturers, it can make lecturers able to maximize all their ideas and creativity in all fields". The emphasis in this category is teaching, research, publication, time and workload, freedom of speech, and expressing any ideas, including community service. Meanwhile, MR who is a lecturer from HE-8 said, "The broad freedom is in the fields of teaching, research, and publication. Besides, also all lecturer activities are outside of tertiary institutions".

Furthermore, variations in activities that can be carried out in the first category are freedom to teach courses, lecture material, and any method used in lectures. The HR who is a lecturer from HE-3 said, "The lecturer has undergone education with a variety of diverse subjects, so it is necessary to provide a breadth of lecturers to teach the desired course with certain learning methods that are considered appropriate". Freedom to speak in any forum, any topic, without fear of having bad consequences from what is done. Freedom to conduct research on anything, whether topic, place, time and how to make research reports. Freedom to publish research results without anyone's intervention. Freedom to do community service without the slightest fear. The emphasis in this category is academic freedom as the right to choose and be involved in selected activities without intervention. Besides, IR who is a lecturer from HE-6 emphasized this, "Academic freedom is the right of a protected lecturer so that he is free to choose and engage in activities without interference from anyone".

The second category is about freedom based on scientific discipline, which means that academic freedom can be understood as the freedom of lecturers to do or not do based on the disciplines occupied. OK, who is a lecturer from HE-10 said, "Academic freedom is its scientific field. Lecturers can do anything as long as it is by scientific fields, outside of that lecturers must be willing to control themselves". The emphasis in this category is the freedom to conduct teaching, research, publication, and community service based on scientific discipline restrictions. JK who is a lecturer from HE-7 stated, "A lecturer must be humble not to come out of his scientific discipline when conducting teaching, research, and service to the community. If you are going to research other scientific fields, you have to 
collaborate with certain scientific experts".

Furthermore, variations in activities that can be carried out in the second category include freedom to teach courses, materials, and any method. Freedom to speak on forums and topics, without fear of having bad consequences from what is done. AK who is a lecturer from HE-1 stated, "Lecturers should only teach by their expertise, so also when speaking also should only be believed if by their fields. Lecturers should not be trusted to speak in academic forums that are not their expertise". Freedom to conduct research based on scientific discipline on the topic, place, time, and method of compiling research reporting. The freedom to publish research results without anyone's intervention based on scientific disciplines that are owned by lecturers. Freedom to serve the community based on the discipline they have. DE who is a lecturer from HE-2 reminded, "Anyone must not limit lecturers in carrying out the vision and mission of higher education in Indonesia, as long as it is by their scientific fields, including in expressing opinions in public, written or oral". The emphasis in this category is academic freedom as the right to choose and be involved in activities chosen based on the discipline of lecturers without intervention.

The third category is about freedom from campus intervention, meaning that academic freedom is understood as the freedom of lecturers to do or not do based on disciplines occupied without campus bureaucratic intervention. LK who is a lecturer from HE-8 said, "The College where the lecturer works is a home for lecturers, as the owner of the academic freedom authority. Therefore, the campus must be the foremost place in freeing lecturers from all restrictions". The emphasis in this category is the freedom to conduct teaching, research, publication, and community service based on disciplinary restrictions, without campus bureaucratic intervention. Meanwhile, variations in activities that can be carried out in the third category are freedom to teach courses, materials, and any method. Freedom to speak on forums and topics, without fear of having bad consequences from what is done. Freedom to conduct research based on scientific discipline, without campus intervention.

The freedom to publish research results without any intervention based on scientific disciplines owned by lecturers, including community service. NK who is a lecturer from HE-8 stated, "Higher education if it limits lecturers in conducting learning, research, publications and expresses written and oral opinions, then the college is just a name. Do not regret if in other places the lecturer gets intervention". The emphasis in this category is academic freedom as the right to choose and be involved in activities chosen based on the discipline of lecturers without interference or fear of intervention from the campus. FK who is a lecturer from HE-4 stated, "Lecturers may not be intervened on campus, as long as they are in the corridor of their scientific fields. If lecturers leave the field of science, universities also need to direct so that the university world loses its authority".

The fourth category is freedom from government intervention, meaning that academic freedom is understood as the freedom of lecturers to do or not do based on the disciplines occupied without government bureaucratic intervention. HK who is a lecturer from HE-5 stated, "I read a lot of books in the past, the government has greatly restrained lecturers from giving lectures, researches, and publications. This violates the government's duty, and there should be no more". The emphasis in this category is freedom of teaching, research, publication, community service based on scientific discipline restrictions, without government bureaucratic intervention. Meanwhile, variations in activities that can be carried out in the fourth category are freedom to teach courses, materials, and any method. Freedom to speak on forums and topics, without fear of having bad consequences from what is done.

Freedom to conduct research based on scientific discipline, without government intervention. The freedom to publish research results without anyone's intervention based on scientific disciplines that are owned by lecturers. Freedom to serve the community by the scientific field they have. CK who is a lecturer from HE-2 stated, "The task of the government is to facilitate the development of science, not to limit lecturers in any field for the advancement of the nation's resources". The emphasis in this category is academic freedom as the right to choose and be involved in activities chosen based on the discipline of lecturers without interference or fear of government intervention. $\mathrm{OK}$, who is a lecturer from HE-10 said that, "One of the heavy burdens for lecturers is if the government intervenes, because the risks can vary for lecturers".

The fifth category is about freedom from industrial intervention, which means that academic freedom is understood as the freedom of lecturers to do or not do based on the disciplines occupied without industrial intervention. NK who is a lecturer from HE-9 said, "I have not had experience intervening in the industrial world, but a few stories of friends who have received projects from the industrial world always feel not free in carrying out academic freedom". The emphasis in this category is the freedom to conduct teaching, research, publication, and community service based on scientific discipline restrictions, without industrial intervention. BR who is a lecturer from HE-1 said, "Many of my friends who want to bring students to the industrial world but are not permitted by the industry. This also includes limiting the freedom of lecturers".

Meanwhile, variations in activities that can be carried out in the fifth category are freedom to teach courses, materials, and any method. Freedom to speak on forums and topics, without fear of having bad consequences from what is done. Freedom to conduct research based on 
scientific discipline, without industrial intervention. Freedom to publish research results without industrial intervention based on scientific disciplines owned by lecturers. Freedom to do community service without industrial intervention. JK who is a lecturer from HE-7 explained, "One of the slow paces of tertiary education is that not the entire industrial world welcomes Cooperation offered by universities such as research and community service". The emphasis in this category is academic freedom as the right to choose and be involved in activities chosen based on the disciplines of the lecturers without interference or fear of industrial intervention.

The sixth category is freedom from religious, ethnic, and gender-based interventions. This means that academic freedom is understood as the freedom of lecturers to do or not do based on disciplines practiced without interventions based on religion, ethnicity, and gender. KR who is a lecturer from HE-7 stated, "As a lecturer, I was restricted several times just because I was a woman. I will conduct research and community service several times, but it is not permitted just because of different religious and ethnic backgrounds. This is an intervention form for lecturers". The emphasis in this category is the freedom to conduct teaching, research, publication, and community service based on disciplinary restrictions, without interventions based on religion, ethnicity, and gender. GR who is a lecturer from HE-4 said, "My freedom as a female lecturer often gets different treatment".

Furthermore, variations in activities that can be carried out in category 6 are the freedom to teach courses, materials, and any method. Freedom to speak on forums and topics, without fear of having bad consequences from what is done. Freedom to conduct research based on scientific discipline, without interventions based on religion, ethnicity, and gender. The freedom to publish research results without anyone's intervention based on scientific disciplines that are owned by lecturers. Freedom to serve the community without religious, ethnic, and gender-based interventions. BR who is a lecturer from HE-1 said, "The most severe intervention I have ever experienced was limited because I am a woman. Even though, academic freedom does not recognize gender. Anyone may not be limited by their fields of expertise". The emphasis in this category is academic freedom as the right to choose and be involved in activities chosen based on the discipline of lecturers without interference or fear of interventions based on religion, ethnicity, and gender. Meanwhile, based on the explanation of the results of in-depth interviews with participants, it can be arranged in a chart about the lecturers' understanding of academic freedom as shown in Figure 1 below.

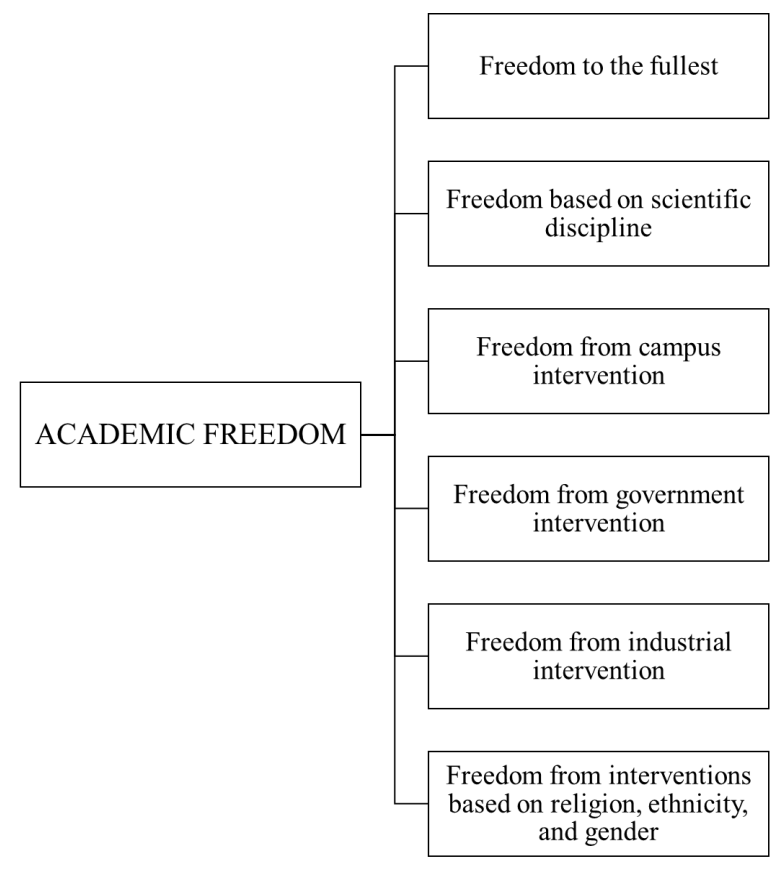

Figure 1. Lecturer Understanding of Academic Freedom

\subsection{Lecturer Experience Got Restrictions on Academic Freedom}

All lecturers interviewed in this research have carried out three main tertiary institutions in Indonesia (teaching, research, and community service). In carrying out the three main institutions of higher education, they always hold to academic freedom. However, in certain situations and conditions in carrying out academic freedom, they get obstacles and interventions from various parties. In this research, based on the experience of the lecturer, getting restrictions on academic freedom can be stated in the sixth category including obtaining teaching assignments outside the field of expertise. Restricting administrative areas in research and getting obstacles from university leaders. Make financial contributions to tertiary institutions when obtaining funding from outside the campus and receive misogynistic treatment from fellow lecturer colleagues. Besides, in the form of persecution, arrest death threats, and reported to the security forces.

More fully, the sixth category of restrictions in implementing academic freedom can be described as follows. The first limitation of academic freedom is to get a teaching assignment outside the field of expertise. All lecturers in this research received teaching assignments from the head of the study program or dean outside the expertise area of the lecturer concerned. The area of expertise referred to here is the knowledge mastered by lecturers based on the education they have taken and the field of expertise mentioned in the certification (professional lecturer certificate) of each lecturer issued by the government. OK, who is a lecturer from HE-10 said, "I have to teach a course that I don't matter because it's different from my area of expertise, but I was helpless, still 
doing the task".

Theoretically, lecturers who teach outside their field of expertise cannot provide good learning so that it harms students. Although they do not get learning services from professional lecturers, as a result, students do not get good scientific mastery. Ethically this violates the spirit of academic freedom that is limited to certain fields of expertise. AK who is a lecturer from HE-1 stated, "I feel pressured when I get a teaching assignment that is beyond my ability. My spirit is different, sorry for students who do not get lecturers, as they should. However, sometimes the situation requires lecturers to teach outside of their expertise. In my opinion, this is contrary to the spirit of academic freedom and the purpose of the establishment of higher education". The second limitation of academic freedom is the limitation of administrative areas in research. Restrictions on academic freedom for lecturers also occur with restrictions on regional areas, which are different from what lecturers want.

Where as the choice of the research area determined by the lecturer is based on academic scientific considerations, but the non-academic administrative authority defeats it so that it cannot conduct research, as it should. JK who is a lecturer from HE-7 said, "On my campus, the organization of lecturer research is limited to certain areas, it should only be done in that region. While many study, programs, and lecturers cannot be facilitated if only research is allowed in the area". As a result, lecturers cannot conduct research facilitated by campus funding. Regional restrictions are usually related to the geographical location where the tertiary institution is located, so the research program always gives priority to the development of the area where the tertiary institution is located. Situations like this restrict lecturers to research with appropriate research locations by scientific considerations. ER, who is a lecturer from HE-3, said, "I haven't done research for two years because of this limitation, as a result, I am deemed not carrying out my obligations as a lecturer, and cannot take care of the promotion of my lecturer rank".

The third limitation of academic freedom is in the form of obstacles from university leaders. The leadership of higher education within certain limits greatly limits and inhibits the growth of academic freedom of lecturers. Restrictions that arise from the leadership of higher education, including reprimands for writing in the media that cause polemic and carry out discussions that are under pressure from certain groups outside the campus. Moreover, I received a reprimand for being a team of experts in a project or expert witness in a court whose opinion was considered detrimental to the college where the lecturer worked or caused polemic in the community. CK who is a lecturer from HE-2 said, "One time I wrote in the newspaper about a problem that was being discussed in the community. The day after it was published in the newspaper, the head of the faculty called me, I was asked to revoke the writing and not repeat it. In addition, my class schedule on campus was suddenly canceled".

There are also university leaders who verbally threaten to terminate their status as lecturers, and or move to another place of assignment if they don't heed the warning. Such higher-level management of the university disturbs the mentality of lecturers. This kind of experience was experienced by HK, who is a lecturer from HE-5 said, "Once I was asked to be an expert witness in the court, shortly after that I got a summons from the head of the college. During the meeting, I was asked to focus on learning on campus, and not continue activities such as the case in the court, if I wanted to continue teaching on this campus. I was shocked to get this warning".

The fourth limitation of academic freedom is in the form of financial contributions to universities when getting funding from outside the campus. College lecturers usually get various funding from outside their tertiary institutions. Lecturer funding obtained from other parties is usually in the form of research, learning development, scholarships, consultants, expert staff, and lecturer contributions in other forms of work. Funding obtained by lecturers is usually from several sources such as other universities, government, private companies, state companies, embassies of other countries, and international donor institutions. In the case of lecturers obtaining funding from outside the campus, the lecturer concerned must contribute funding to the campus where he works. LK who is a lecturer from HE-8 said, "On my campus, all lecturers who get outside funding for any purpose, are always deducted for the campus for various reasons. This deduction is troublesome because it is related to accountability for the use of funds".

The amount of contribution is quite diverse by the policies of each tertiary institution. In general, in the form of a percentage of the number of funds obtained, between 5-15 percent. DK who is a lecturer from HE-2 also admitted, "I always cut 5-15 percent for campus every time I get funding. The deduction depends on how much money we get". Lecturers as a form of limiting academic freedom consider the contribution of lecturers to tertiary institutions. Meanwhile, because the funds obtained by lecturers from other parties are usually in rational amounts and only enough for a program that suits their designation. With the obligation of lecturers to contribute, they must take financing items in the program, thereby reducing the quality and even the quantity of the program. While in reporting to other funding institutions, lecturers must report exactly as stated in the cooperation agreement or program. FK who is a lecturer from HE-4, stated emphatically, "Withholding funds for the program by the campus violates academic freedom because the lecturer must be responsible for the finances deposited in the activities carried out".

Fifth limitation of academic freedom is in the form of getting misogynistic treatment from fellow lecturer colleagues. It is unfortunate that misogynistic treatment 
also still occurs in universities. Misogynist is an attitude or behavior that places women discriminatory. Misogynist treatment often occurs in lecturers who pursue gender studies. Misogynistic treatment among fellow lecturers takes place in daily interactions and official meetings. The most common form is expressions as told by MR, who is a lecturer from HE-8, "In daily life lecturers like me often get abuse treatment, for example, expressions, be careful there are gender activists. Besides, in the official forum, each will speak welcome, please those who are gender experts, then followed by certain body gestures and laughing together".

A similar experience was also recognized by GR who is a lecturer from HE-4 who got this treatment from a colleague, "If gender experts speak, I cannot comment. Then the forum feels cheerful and boisterous". This misogynist treatment puts psychological pressure on lecturers, especially those who pursue gender studies. As the recognition of BR who is a lecturer from HE-1 said, "Such misogynistic treatment is very hindering female or even male lecturers who have a good gender perspective. If the lecturer is still new, it can be withdrawn to not pursue gender". The sixth limitation of academic freedom in the form of persecution, arrest, death threats, reported to the security forces. Limiting the academic freedom of lecturers using persecution, arrest, and even death threats are the banalest form in the history of human civilization.

This research found that the lecturer received such treatment because of the academic activities undertaken by the lecturer. One of the lecturers who received this kind of treatment stated, after he criticized the sensitive policy, his wife got a telephone call to remind her husband. AK who is a lecturer from HE-1 stated, "I once criticized the policy. When I got home, my wife was told by a stranger, reminding me not to mess around if I wanted to stay safe as a family". Some colleagues of the lecturer asked those concerned to apologize to the leadership. The next day strangers while walking around campus persecuted the lecturer. While in treatment, the person concerned received death threats by telephone. A month after the incident of abuse, someone reported to the police on charges of defamation. AK who is a lecturer from HE-1 said, "I am reminded by colleagues to stop criticizing. Until one day, I was persecuted by strangers and entered a hospital. Even though at the hospital, the threat to me continued. Until one day, after I recovered, I was reported to the police for defamation. Alhamdulillah in court I was found not guilty".

The same thing happened to lecturers whose research results were judged by certain groups to be wrong, so they were asked to revoke their research results. Rejection of the results of this research occurred in many cities in the form of demonstrations and rejection or the dissolution of discussion forums that would discuss the results of this research. NK who is a lecturer from HE-9 said, "My research caused a polemic, my family and I were threatened, there were demonstrations everywhere, I was asked to withdraw. However, until now I have not pulled it off. Finally, it died down on its own". Meanwhile, based on the explanation of the results of in-depth interviews with participants, it can be arranged in a chart about the experience of lecturers getting restrictions on academic freedom as shown in Figure 2.

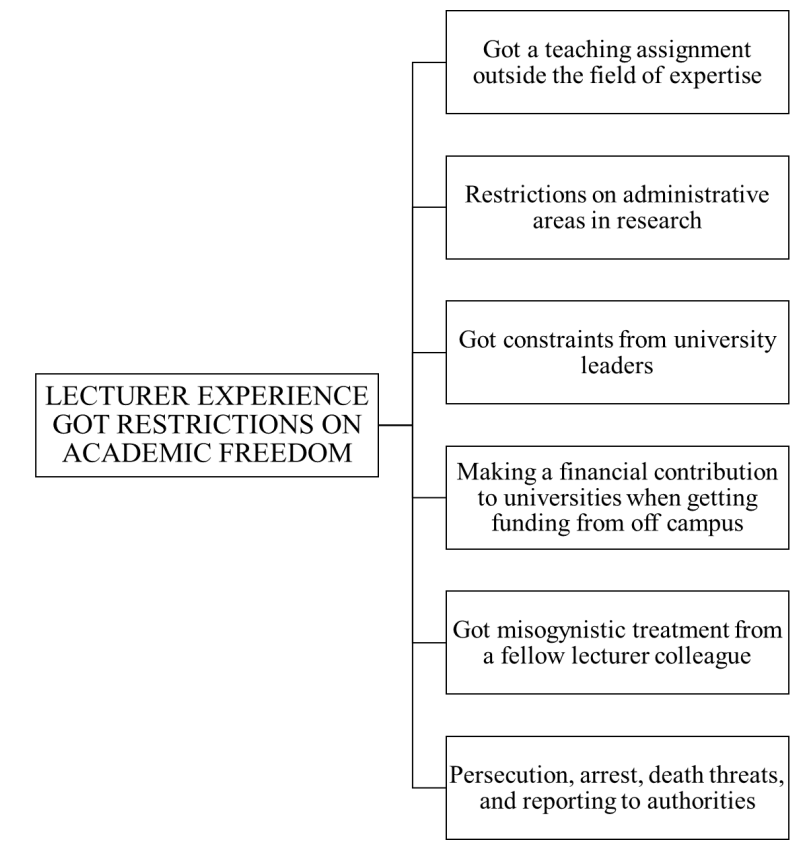

Figure 2. The Experience of Lecturers is Restricted in Academic Freedom

\subsection{Lecturer Strategy in Maintaining Academic Freedom}

Although in general the lecturers when facing the threat of academic freedom lose, and surrender, without making a fight. However, in some cases, they continue to struggle so that their academic rights are maintained. Some things that lecturers do when they get restrictions on academic freedom include inviting dialogue to those who are holding back. Some succeed so that the activity can be carried out, but in many other cases, the dialogue does not find common ground. As a result, lecturers cannot continue their academic activities or continue to carry out their academic activities clandestinely. Although in general the lecturers when facing the threat of academic freedom lose, and surrender, without making a fight. However, in some cases, they continue to struggle so that their academic rights are maintained. Some things that lecturers do when they get restrictions on academic freedom include inviting dialogue to those who are holding back. Some succeed so that the activity can be carried out, but in many other cases, the dialogue does not find common ground. As a result, lecturers cannot continue their academic activities or continue to carry out their academic activities clandestinely.

In addition, based on the experience of lecturers in 
maintaining and maintaining academic freedom, there are 6 practical steps they take, which in practice always adapts to the scale and scope of the restrictions they experience. The sixth strategy undertaken by the dossier in dealing with restrictions on academic freedom is direct conveying disagreement with the decisions taken, writing letters to leaders, inviting dialogue to the party who is hindering, asking for protection from the security forces (the police), making a defense by writing opinions, letters of readers, press releases for mass media, and or posted on the website, as well as taking part outside universities by establishing their own institutions such as, both formal, non-formal, or non-governmental educational institutions. NK who is a lecturer from HE-9 said, "I am very critical of everything that impedes academic freedom. Therefore, I always invite dialogue on that which inhibits my freedom. I sometimes succeed, although many have failed, this is very important for the lecturers to do so that there is not a lot of academic freedom going forward".

LK who is a lecturer from HE-8 also revealed his experience, "I always invite dialogue whenever facing the threat of academic freedom, such as cutting funds from campus. I approached the leadership and asked for an explanation of why it was done. The result is I no longer cut, but my other friends, still cut". Besides, the strategies undertaken by lecturers can also ask for protection from the authorities. This step is successful and lecturers can carry out their academic activities, but the majority of lecturers lose when the obstacles to academic freedom involve the masses of certain groups. NK who is a lecturer from HE-9 in his experience stated, "When I was threatened by many parties related to my research results, I immediately reported and asked for protection from the police. As a result, I was not treated cruelly, like persecution". However, a different experience happened to $\mathrm{AK}$ who is a lecturer from HE-1 who said, "I will hold discussions twice, and always fail because of the threat of disbanding. The effort that I did with friends asking for protection to the security apparatuses, did not work. Even though the discussion is on campus".

Furthermore, defend by writing opinions, letters of readers, press releases for mass media, and or posted on the college website. Lecturers who have an activist background in the Movement and have networks at the local, national, and even international levels usually carry out this step. The results are not always apparent, but the courage to write in public can give an emphasis back to opponents of academic freedom. AK who is a lecturer from HE-1 said, "When my discussion program failed, the security forces also suggested canceling, what I did was write on the website and make a press release. The aim is to remind the public and the state apparatus that academic freedom is undermined. Maybe the results are not short term now, but one day it might be a different story if there is a similar event".

Strategies by taking part outside universities by establishing their institutions such as Educational Institutions or Non-Governmental Organizations can also be carried out by lecturers. Many lecturers adopt this pattern because they feel more comfortable, secure, and strategic, and can achieve their goals, compared to continuing to use the identity of higher education. BR who is a lecturer from HE-1 said, "Instead of messing around with complicated administrative matters in tertiary institutions, it is better just take action outside the campus that allows maximum creativity. Just on campus, just teaching, especially". Besides, ER who is a lecturer from HE-3 said, "Since I felt hampered on campus, and I failed to fight for the rights of academic freedom, I immediately joined an international institution whose work was flexible. I remain a lecturer but only teach. Research, community service I do with off-campus". Working outside of tertiary institutions is also considered to provide better and more productive results than just acting on campus. MR who is a lecturer from HE-8, shared experience, "Once I established the Institute, creative work, I can also achieve a broader reputation very quickly".

In addition, to face the challenges of limiting academic freedom as listed in Figure 2, the steps taken by the participants are as follows. Immediately convey disagreement with the decision taken. This step is carried out by male and female lecturers who pursue gender. Raising objections directly is usually immediately visible, because it occurs at formal and informal meetings, in everyday life at the university. MR of HE-8 stated, "In formal meetings or informal or casual meetings, if someone says, behaves, or behaves misogynistically, I immediately declare my disapproval firmly. So far, my experience is that this step is quite successful, usually they directly approach him or apologize". BR expressed his experience, "I am very sensitive to all things that are misogynistic. All of my students, regardless of men or women, if I humiliate each other, both verbally and in writing, I immediately remind them, right then and there. I always affirm, don't repeat it anywhere". Nevertheless, ensure that students have good gender sensitivity, GR from HE-4 said, "If there are students my exams give misogynistic answers, I make sure they will not graduate and I will remedy. I always convey this to students at the initial meeting".

Write a letter to the leadership. This step is taken by the lecturer in the initial stages, and sometimes after a meeting with the leadership. OK from HE-10 relates, "I once got a teaching assignment outside of my area of expertise, I immediately confronted and raised objections to the leadership. At the meeting there was no way out. I then wrote an official letter stating I objected yes to his arguments, then the teaching assignment outside my expertise was reduced. Not bad, even though there are still subjects not my field that I should be able to too". ER from HE-3 also made a letter to the leadership when it was not allowed to carry out research outside the 
geography established by the university, but to no avail. ER recounts, "I twice sent an objection letter to the leadership of the campus because they refused to fund my research with reasons outside of geography, twice the letter I presented, twice also there was no response until now".

\section{Discussion}

In this research found sixth categories of lecturers understanding in Indonesia about academic freedom. The sixth groups of categories of understanding academic freedom include the first category of freedom to the broadest. The second category is about freedom based on scientific discipline and the third category is about freedom from campus intervention. The fourth category is freedom from government intervention and the fifth category is freedom from industrial intervention. Meanwhile, the sixth category is about freedom from interventions based on religion, ethnicity, and gender. These sixth categories, there is one that is in a very extreme range that understands academic freedom as the widest freedom without any limitations in the field of science and the field of academic work (teaching, research, and community service). However, the other five categories give a moderate meaning, that academic freedom possessed by academics is limited by their respective scientific fields in conducting teaching, research, publishing, and community service. Lecturers understand this freedom as freedom from campus, government, industry, and religion, ethnicity, and gender. The results of this research reinforce the notion that general academic freedom is open to the possibility of interpretation and debate $[33,34]$. Textually the general statement of academic freedom is seen in the document [35].

The sixth categories produced in this research are also broader than the categories of understanding academic freedom carried out by social science researchers in Australia [36,37]. Another peculiarity of the results of this research is that lecturers emphasize academic freedom in teaching, research, publishing, and community service. While social science researchers in Australia emphasized aspects of teaching, research, and publishing [38,39]. Based on the sixth category of meaning, it can be concluded that academic freedom is the freedom of lecturers to do or not do something based on the disciplines occupied. The emphasis of this meaning is the freedom to conduct teaching, research, publication, and community service based on the limitations of scientific disciplines, without intervention from the campus, government, industry, religious groups, ethnicity, and gender.

The meaning of academic freedom of the lecturers is closer to the meaning of an individual nature, which is free. On the contrary, the lecturers did not give meaning and interpretation in collegial-disciplinary and institutional aspects. Academic freedom for an institution includes autonomy or self-government to determine academic policy, a balance between teaching and research, staffing ratio, appointment, promotion and student discipline, curriculum, standards, examinations, and awarding degrees and diplomas $[40,41]$. Besides, with control over resources to carry out activities on all policies [42], does the meaning of academic freedom of lecturers relate to their experience in implementing academic freedom? For this reason, it is important to discuss the results of this research on aspects of the experience of lecturers who face obstacles in exercising academic freedom.

Based on experience, it turns out lecturers in Indonesia get restrictions in the sixth category including the first, get-teaching assignments outside the field of expertise. This is a new finding because no lecturer feels academic freedom is limited because he is given the task of teaching certain subjects. Moreover, what often happened before was the limitation of lecturers in conducting scientific speeches such as seminars, workshops, and Dies Natalis speeches $[43,44]$. Second, administrative area restrictions in research. This is different from the case that often occurs, namely the prohibition of researching because of taking sensitive themes [45,46]. Thirdly, there are obstacles from university leaders, in the form of reprimands and threats of dismissal. Cases like this are also typical, which often occur from the past to the present day. Fourth, financial contribution to universities when getting funding from outside campus. This is closely related to the increasingly great commercialization and industrialization of higher education, where the logic of higher education is calculated like business and industry $[47,48]$. Fifth, they received misogynistic treatment from fellow lecturer colleagues. Misogynist, which is a form of feelings, attitudes, and behaviors that hate and be aware of women, is very dangerous and can suppress women [49,50]. Sixth, persecution, arrest, death threats, reported to the security forces. The treatment of the banalest lecturers is still happening as in the beginning the tertiary institutions began to form in the world $[51,52]$.

University leaders, university administrators, fellow lecturer colleagues, government officials, and community groups carried out perpetrators of limitation of academic freedom in this research. This is different from the previous research that concluded that groups outside the internal college carried out the perpetrators of restrictions and threats to academic freedom. This research also did not find any restrictions on academic freedom by industry, as happened in many cases $[53,54]$. These sixth categories of restrictions on academic freedom reinforce the results of previous studies that lecturers in Indonesia are under pressure and danger [55-57]. Emphasis on academic freedom also occurs in various parts of the world. This emphasis and limitation on academic freedom always remind us that since the beginning of the tertiary 
institution's civilization, it is not easy to uphold and continues to this day.

When lecturers in Indonesia face the pressures and barriers to academic freedom, they take various tactical and strategic steps to adapt to their respective situations and conditions. The lecturers take four things; the first is inviting dialogue to the obstacle. Second, ask for protection from the authorities. Both of these steps are sometimes successful and lecturers can carry out academic activities, but the majority of lecturers lose when inhibitors of academic freedom involve the masses of certain groups. Third, make a defense by writing opinions, letters of readers, press releases for mass media, and or posted on the college website. The results are not always apparent, but the courage to write in the public can give an emphasis back to opponents of academic freedom, that lecturers take the fight $[58,59]$.

Fourth, take part outside universities by establishing research institutes or non-governmental organizations, so that lecturers can exercise their academic freedom more safely without using their identity as lecturers. The steps taken by lecturers have similarities in the aspects of dialogue and writing in the media, but are different in taking the steps of establishing a research institution or non-governmental organization $[60,61]$. The way out is also different from that suggested by strengthening networks of academics, professional associations, and international institutions and strengthening institutions that pay serious attention to academic freedom $[62,63]$. Differences The steps are taken are due to differences in the perpetrators of academic freedom restrictions, whether by universities, the government, or certain community groups. Secondly, differences in scope (local, national, and international) and sources of data used (news media, in-depth interviews, observations, and documentation).

\section{Conclusions and Implications}

This research explores the meaning of academic freedom by lecturers in Indonesia. This research found that academic freedom is the freedom of lecturers to do or not do something based on their disciplines, in the aspects of teaching, research, publication, and community service which, without intervention from the campus, government, industry, religious groups, ethnic groups, and gender. The meaning of academic freedom of the lecturers is closer to the meaning of individual nature. On the contrary, the lecturers did not give meaning and interpretation in collegial-disciplinary and institutional aspects; lecturer experience in getting restrictions in carrying out academic freedom in the form of getting teaching assignments outside the field of expertise.

Restricting the administrative area of research and getting obstacles from the leadership of the university. Make financial contributions to tertiary institutions and receive misogynistic treatment. Furthermore, persecution, arrest, and death threats. Leaders of universities, fellow lecturer colleagues, government officials, and community groups carried out perpetrators of restrictions on academic freedom in this research. When facing limitations in exercising academic freedom, the lecturer carries out various strategies that include directly conveying disagreement with the decisions taken, writing letters to leaders, inviting dialogue to the party who is hindering, asking for protection from the security forces (the police), making a defense by writing opinions, letters of readers, press releases for mass media, and or posted on the website, as well as taking part outside universities by establishing their own institutions such as, both educational institutions formal, non-formal, or non-governmental organizations. The sixth strategies concluded in this research sometimes yielded positive results, but more failure occurred.

The various interpretations of academic freedom given by lecturers in Indonesia show that not all lecturers have a comprehensive enough understanding. This also reinforces the results of previous studies that conceptually academic freedom in general, thus opening the door to diverse interpretations, interpretations, and meanings. The clearest evidence of the use of interpretations of academic freedom is the threat to lecturers who exercise their academic freedom rights. Restrictions on academic freedom in this research turned out to be done more by internal universities. The strategy is taken by the lecturer when he got restrained academic freedom was not yet effective, to stay on the path of academic freedom. The situation of violations of academic freedom is still being carried by internal universities and parties outside the university, so this is a strong warning that it is urgent to do a broader conceptualization to minimize interpretation and minimize the misuse of interests. In addition to strengthening networks between lecturers and international institutions that are concerned with academic freedom can provide bargaining value in upholding academic freedom at various levels.

\section{Acknowledgments}

We thank the participants who have actively contributed in this research. We also thank the lecturers of the Graduate School, Yogyakarta State University for guiding this research.

\section{REFERENCES}

[1] A. Freedom and I. Comments, "The 1940 statement of principles on academic freedom and tenure", Freedom and Tenure in the Academy, pp. 3-77, 2014.

[2] C. Hutchison, "Academic freedom in the college classrooma collision of interests", Journal of Behavioral and Applied 
Management, vol. 20, no. 1, pp. 1-16, 2020.

[3] P. G. Altbach, "Problems and possibilities: The US academic profession", Studies in Higher Education, vol. 20, no. 1, pp. 27-44, 1995.

[4] S. Marginson, "Limitations of human capital theory", Studies in Higher Education, vol. 44, no. 2, pp. 287-301, 2019.

[5] M. L. Steinborn and E. A. Nusbaum, "Cripping human rights education with disability studies: An undergraduate reading list”, Educational Studies, vol. 55, no. 4, pp. 489-504, 2019.

[6] G. Nabi, A. Walmsley, F. Liñán, I. Akhtar, and C. Neame, "Does entrepreneurship education in the first year of higher education develop entrepreneurial intentions? The role of learning and inspiration”, Studies in Higher Education, vol. 43 , no. 3 , pp. 452-467, 2018

[7] M. Zakerian, Z. Sadoughi, A. Nabavi, and R. Mahdi, "Realization of peace from the perspective of the role of higher education in the field of diplomacy: Experience of academic diplomacy in Iran", Journal of Fundamental and Applied Sciences, vol, 9, no. 1S, pp. 184-203, 2017.

[8] S. Stein, V. D. O. Andreotti, and R. Suša, "Beyond 2015, within the modern/colonial global imaginary? Global development and higher education", Critical Studies in Education, vol. 60, no. 3, pp. 281-301, 2019.

[9] Y. Rahmawati, S. F. Ramadhani, and Afrizal, "Supporting Assessment in Education: E-Assessment Interest in Physics", Universal Journal of Educational Research, vol. 8, no. 1, pp. 72-82, 2020. DOI: 10.13189/ujer.2020.080110

[10] S. A. Popenici and S. Kerr, "Exploring the impact of artificial intelligence on teaching and learning in higher education", Research and Practice in Technology Enhanced Learning, vol. 12, no. 1, pp. 22, 2017.

[11] J. D. Aberbach and T. Christensen, "Academic autonomy and freedom under pressure: Severely limited, or alive and kicking?", Public Organization Review, vol. 18, no. 4, pp. 487-506, 2018.

[12] B. Maxwell, D. I. Waddington, and K. McDonough, "Academic freedom in primary and secondary school teaching", Theory and Research in Education, vol. 17, no. 2, pp. 119-138, 2019.

[13] A. Martin-Sardesai, H. Irvine, S. Tooley, and J. Guthrie, "Government research evaluations and academic freedom: The UK and Australian comparison", Higher Education Research \& Development, vol. 36, no. 2, pp. 372-385, 2017.

[14] B. Baser, S. Akgönül, and A. E. Öztürk, "Academics for peace in Turkey: A case of criminalizing dissent and critical thought via counterterrorism policy", Critical Studies on Terrorism, vol. 10, no. 2, pp. 274-296, 2017.

[15] M. Wood and F. Su, "What makes an excellent lecturer? Academics' perspectives on the discourse of 'teaching excellence' in higher education", Teaching in higher education, vol. 22, no. 4, pp. 451-466, 2017.

[16] A. Hedgecoe, "Reputational risk, academic freedom, and research ethics review", Sociology, vol. 50, no. 3, pp. 486-501, 2016.

[17] T. Abbas and A. Zalta, "You cannot talk about academic freedom in such an oppressive environment': Perceptions of the we will not be a party to this crime! Petition signatories", Turkish Studies, vol. 18, no. 4, pp. 624-643, 2017.

[18] D. R. Sadler, "Academic achievement standards and quality assurance", Quality in Higher Education, vol. 23, no. 2, pp. 81-99, 2017.

[19] L. Lange, "Thinking academic freedom", Arts and Humanities in Higher Education, vol. 15, no. 2, pp. 177-186, 2016.

[20] T. Karran, "Academic freedom: In justification of a universal ideal", Studies in Higher Education, vol. 34, no. 3, pp. 263-283, 2009.

[21] P. Taylor, "Thinking allowed in the academy: International human rights law and the regulation of free speech and academic freedom under the "model code", The University of Queensland Law Journal, vol. 39, no. 1, pp. 117-146, 2020.

[22] Republik Indonesia, "Undang-Undang Republik Indonesia Nomor 12, Tahun 2012, tentang Pendidikan Tinggi”, 2012. [Republic of Indonesia, "Constitution of the Republic of Indonesia Number 12, 2012, concerning Higher Education", 2012].

[23] Republik Indonesia, "Undang-Undang Republik Indonesia Nomor 14, Tahun 2005, tentang Guru dan Dosen", 2005. [Republic of Indonesia, "Constitution of the Republic of Indonesia Number 14, 2005, concerning Teachers and Lecturers", 2005].

[24] Republik Indonesia, “Undang-Undang Republik Indonesia Nomor 20, Tahun 2003, tentang Sistem Pendidikan Nasional", 2003. [Republic of Indonesia, "Constitution of the Republic of Indonesia Number 20, 2003, concerning the National Education System", 2003].

[25] Masduki, "Assessing Indonesian journalist threats: Cases, actors, and motives", Media Asia, vol. 44, no. 1, pp. 25-32, 2017.

[26] A. J. Orr, "Teaching Sociology: The precariousness of academic freedom", Sociological Perspectives, vol. 62, no. 1, pp. 5-22, 2019.

[27] H. Woodhouse, "The contested terrain of academic freedom in Canada's Universities: Where are we going?", American Journal of Economics and Sociology, vol. 76, no. 3, pp. 618-647, 2017.

[28] J. W. Creswell, W. E. Hanson, V. L. Clark Plano, and A. Morales, "Qualitative research designs: Selection and implementation", The counseling psychologist, vol. 35, no. 2, pp. 236-264, 2007.

[29] C. Moustakas, "Phenomenological research methods", Sage publications, 1994.

[30] J. Mailool, H. Retnawati, S. Arifin, A. T. Kesuma, and H. Putranta, "Lecturers' experiences in teaching soft skills in the teaching profession education program (TPEP) in Indonesia", Problems of Education in the 21st Century, vol. 78, no. 2, pp. 215-234, 2020.

[31] H. Copes, W. Tchoula, F. Brookman, and J. Ragland, "Photo-elicitation interviews with vulnerable populations: Practical and ethical considerations", Deviant Behavior, vol. 39, no. 4, pp. 475-494, 2018. 
[32] A. Bager-Elsborg, "How lecturers' understanding of change is embedded in disciplinary practices: a multiple case study", Higher Education, vol. 76, no. 2, pp. 195-212, 2018.

[33] C. Owen, "The 'internationalization agenda and the rise of the Chinese university: Towards the inevitable erosion of academic freedom?", The British Journal of Politics and International Relations, vol. 22, no. 2, pp. 238-255, 2020.

[34] Maison, Darmaji, Astalini, D. A. Kurniawan, Sumaryanti, and R. Perdana, "Supporting Assessment in Education: E-Assessment Interest in Physics", Universal Journal of Educational Research, vol. 8, no. 1, pp. 89-97, 2020.

[35] E. M. Fisher, "The tangled roots of Vīraśaivism: On the Vīramāheśvara textual culture of Srisailam", History of Religions, vol. 59, no. 1, pp. 1-37, 2019.

[36] S. Ashton, K. McDonald, and M. Kirkman, "What does 'pornography' mean in the digital age? Revisiting a definition for social science researchers", Porn Studies, vol. 6, no. 2, pp. 144-168, 2019.

[37] K. Vähäsantanen, S. Paloniemi, E. Räikkönen, and P. Hökkä, "Professional agency in a university context: Academic freedom and fetters", Teaching and Teacher Education, vol. 89, pp. 103000, 2020.

[38] R. Boden and D. Epstein, "A flat earth society? Imagining academic freedom", The Sociological Review, vol. 59, no. 3, pp. 476-495, 2011.

[39] F. Sultana, "The false equivalence of academic freedom and free speech", ACME: An International Journal for Critical Geographies, vol. 17, no. 2, pp. 228-257, 2018.

[40] H. Putranta and J. Jumadi, "Physics teacher efforts of Islamic high school in Yogyakarta to minimize students' anxiety when facing the assessment of physics learning outcomes", Journal for the Education of Gifted Young Scientists, vol. 7, no. 2, pp. 119-136, 2019.

[41] C. B. Cohen, "World-class universities and institutional autonomy in China", International Higher Education, no. 99, pp. 26-28, 2019.

[42] R. M. Simpson, "The relation between academic freedom and free speech", Ethics, vol. 130, no. 3, pp. 287-319, 2020.

[43] H. C. Hsieh and H. L. Hsieh, “Undergraduates' out-of-class learning: Exploring EFL students' autonomous learning behaviors and their usage of resources", Education Sciences, vol. 9, no. 3, pp. 159, 2019.

[44] E. W. Neblett Jr, "Diversity (psychological) science training: Challenges, tensions, and a call to action", Journal of Social Issues, vol. 75, no. 4, pp. 1216-1239, 2019.

[45] L. Jackson, "Academic freedom of students", Educational Philosophy and Theory, vol. 3, no. 2, pp. 1-8, 2020.

[46] T. Aarrevaara, "Academic freedom in a changing academic world”, European Review, vol. 18, no. 1, pp. 55-69, 2010.

[47] J. Reichertz, "Automating security in and around soccer stadiums through camera systems? Report on a research project", European Journal for Security Research, vol. 5, no. 1 , pp. 59-81, 2020.

[48] G. Ritzer, "The McDonaldization of society 20th-anniversary edition (1st ed.)", The Sage United States,
2013.

[49] J. Butler, "Academic freedom and the critical task of the university", Globalizations, vol. 14, no. 6, pp. 857-861, 2017.

[50] H. Mason-Bish and I. Zempi, "Misogyny, racism, and Islamophobia: Street harassment at the intersections", Feminist Criminology, vol. 14, no. 5, pp. 540-559, 2019.

[51] T. Pherali, "School leadership during violent conflict: Rethinking education for peace in Nepal and beyond", Comparative Education, vol. 52, no. 4, pp. 473-491, 2016.

[52] J. Salmi, "Academic governance and leadership in Vietnam: Trends and challenges", Journal of International and Comparative Education (JICE), pp. 103-118, 2019.

[53] R. W. Hefner, "The study of religious freedom in Indonesia", The Review of Faith \& International Affairs, vol. 11, no. 2, pp. 18-27, 2013.

[54] L. S. Gottfredson, "Lessons in academic freedom as lived experience", Personality and Individual Differences, vol. 49, no. 4, pp. 272-280, 2010

[55] B. Streitwieser, K. Allen, and K. Duffy-Jaeger, "Higher education in an era of violent extremism: Exploring tensions between national security and academic freedom", Journal for Deradicalization, vol. 18, pp. 74-107, 2019.

[56] I. Ulum, R. R. Harviana, S. Zubaidah, and A. W. Jati, "Intellectual capital disclosure and prospective student interest: Indonesian perspectives", Cogent Business \& Management, vol. 6, no. 1, pp. 1707041, 2019.

[57] C. Thompson, "Debating academic freedom. Educational-philosophical premises and problems", Educational Philosophy and Theory, pp. 1-11, 2020.

[58] A. Kramer and R. Zinbarg, "Recalling courage: An initial test of a brief writing intervention to activate a 'courageous mindset' and courageous behavior", The Journal of Positive Psychology, vol. 14, no. 4, pp. 528-537, 2019.

[59] S. A. S. Arifin, H. Retnawati, J. Mailool, and H. Putranta, "The factors that influence reading ability the Hijaiyah alphabet on pre-school children", Journal for the Education of Gifted Young Scientists, vo. 8, no. 2, pp. 667-680, 2020.

[60] E. Härkönen and A. Stöckell, "Cultural sustainability in art - based interdisciplinary dialogue", International Journal of Art \& Design Education, vol. 38, no. 3, pp. 639-648, 2019.

[61] E. Beerkens, "Global models for the national research university: adoption and adaptation in Indonesia and Malaysia", Globalisation, Societies and Education, vol. 8, no. 3, pp. 369-391, 2010.

[62] S. J Sollid, P. Dieckman, K. Aase, E. Søreide, C. Ringsted, and D. Østergaard, "Five topics health care simulation can address to improve patient safety: Results from a consensus process", Journal of patient safety, vol. 15, no. 2, pp. 111, 2019.

[63] G. S. A kerlind and C. Kayrooz, "Understanding academic freedom: The views of social scientists", Higher Education Research and Development, vol. 22, no. 3, pp. 327-344, 2003. 